\title{
Funding Type Code
}

National Cancer Institute

\section{Source}

National Cancer Institute. Funding Type Code. NCI Thesaurus. Code C93572.

A coded value specifying the kind of money and resources that are being used to fund the activity. 